\title{
PEMAHAMAN SISWA TERHADAP PERMASALAHAN BANGUN DATAR BERDASARKAN TEORI APOS
}

\author{
Azi Yustriawan ${ }^{1}$, Ella Winanda ${ }^{2}$, Siti Aisyah ${ }^{3}$ \\ Matematika, Fakultas Matematika dan IImu Pengetahuan Alam, Universitas Negeri Medan \\ ellawinanda3@gmail.com
}

\begin{abstract}
A good understanding of mathematical concepts can help students to solve problems with flat shapes. Therefore, it is necessary to have a theory to find out how far the achievement of the indicators of student understanding on the flatshaped material is. This study aims to analyze how students understand the problem of flat shapes based on apos theory. This type of research is a descriptive qualitative research. The subjects in this study were 6th grade elementary school students. Data collection was carried out by conducting a written test in the form of 1 essay question about the flat material which was filled in via a google form. And one student's answer will be chosen to be used as a research sample. The result of this research is that the answer from one of the selected students is able to solve the problem of flat shape with APOS theory.
\end{abstract}

Keywords: Student Understanding, APOS Theory

\begin{abstract}
Abstrak: Pemahaman konsep matematika yang baik dapat membantu siswa untuk menyelesaikan permasalahan bangun datar. Maka dari itu, diperlukan adanya suatu teori untuk mengetahui sudah sejauh mana pencapaian indikator pemahaman siswa pada materi bangun datar. Penelitian ini bertujuan untuk menganalisis bagaimana pemahaman siswa terhadap permasalahan bangun datar berdasarkan teori apos. Jenis penelitian ini ialah penelitian kualitatif yang bersifat deskriptif. Adapun yang menjadi subjek dalam penelitian ini adalah siswa kelas 6 Sekolah Dasar. Pengumpulan data dilakukan dengan melakukan tes tertulis berupa 1 soal essay tentang materi bangun datar yang di isi melalui google form. Dan akan dipilih satu jawaban siswa untuk dijadikan sampel penelitian. Hasil dari penelitian ini jawaban dari salah satu siswa yang terpilih mampu menyelesaikan permasalahan bangun datar dengan teori APOS.
\end{abstract}

Kata kunci: Pemahaman Siswa, Teori APOS

\section{Pendahuluan}

Matematika merupakan ratunya ilmu. Siswa yang mempelajari matematika diharapkan menjadi unik, karena matematika merupakan mata pelajaran yang logis, kritis, cermat, kreatif, dan memerlukan pemikiran inisiatif dari 
siswa. Hal ini sejalan dengan pendapat [4] bahwa pembelajaran matematika dapat melatih kemampuan berpikir kritis, kreatif dan berpikir positif yang dibutuhkan manusia untuk memecahkan berbagai masalah.

Namun seringkali siswa menganggap Matematika adalah momok yang menakutkan untuk mereka [1]. Hal ini disebabkan kurangnya pemahaman serta penguasaan mereka pada materi Matematika itu sendiri. Memahami dan menguasai suatu konsep merupakan prasyarat untuk menguasai materi atau konsep selanjutnya. Tetapi, persyaratan itu terkadang tidak semua terlaksana, sehingga siswa tidak benar-benar memahami konsep dasar. Akibatnya, siswa memiliki pemahaman matematika yang buruk [3]. Sangat penting memahami sebuah konsep dalam ilmu pengetahuan yang sedang di pelajari. Pemahaman yang baik tentang konsep akan memajukan siswa ke tingkat kognisi yang lebih tinggi. Siswa dapat menghubungkan atau mengkorelasikan konsep jika mereka memiliki pemahaman yang baik tentangnya. Selain itu, konsep tersebut dapat digunakan untuk memecahkan permasalahan dari mulai yang sederhana hingga ke permasalahan yang lebih kompleks [6].

Pemahaman konsep matematika yang baik dapat membantu siswa untuk menyelesaikan permasalahan bangun datar. Maka dari itu, diperlukan adanya suatu teori untuk mengetahui sudah sejauh mana pencapaian indikator pemahaman siswa pada materi bangun datar.

APOS adalah teori konstruktivis tentang bagaimana anak-anak mempelajari konsep matematika [2]. Teori APOS adalah teori yang mempelajari bagaimana orang mempelajari konsep-konsep matematika. Teori ini mengemukakan bahwa dalam membangun sebuah konsep matematika, individu melalui tahap-tahap aksi, proses, objek, dan skema.kemampuan pemahaman konsep siswa dikategorikan menjadi kategori sangat baik, kategori baik, dan kategori kurang. 
Menurut [5], kerangka APOS (Aksi, Proses, Objek, Skema) sebagai berikut:

- Aksi/Tindakan

a) Kegiatan yang menyangkut hal-hal prosedural

b) Fokus pada algoritma dalam memecahkan masalah

c) Cenderung menyelesaikan masalah sesuai dengan contoh yang diberikan

d) Hanya menerapkan konsep matematika dari rumus formal sesuai untuk contoh

e) Memerlukan panduan rinci untuk memecahkan masalah (transformasi)

- Proses

a) Tidak memerlukan panduan untuk mengubah

b) Mampu menjelaskan langkah-langkah transformasi terstruktur tanpa benar-benar melakukannya

c) Kegiatan ini merupakan pemahaman prosedural

- Object

a) Mampu melakukan tindakan dan proses terhadap matematika objek yang ditemui

b) Proses ini merupakan pemahaman konseptual

c) Mampu menjelaskan secara logis dan struktural transformasi tersebut selesai

d) Mampu menjelaskan sifat-sifat konsep matematika

- Skema

a) Mampu menghubungkan berbagai konsep matematika atau transformasi konsep pada kegiatan tindakan, proses, atau obyek 
b) Dapat menghubungkan tindakan, proses, objek dengan lainnya yang diketahui sebelumnya properti

c) Memahami rumus-rumus yang diperlukan untuk menyelesaikan masalah.

\section{Metode Penelitian}

Jenis penelitian ini merupakan penelitian kualitatif yang bersifat deskriptif. Pengumpulan data dilakukan dengan melakukan tes tertulis berupa soal essay tentang materi bangun datar yang di isi melalui google form yang telah disediakan peneliti. Adapun yang menjadi subjek dalam penelitian ini adalah siswa/siswi kelas VI SD. Kemudian akan dipilih secara acak jawaban dari salah satu siswa untuk dijadikan sampel penelitian. Data dianalisis dengan deskriptif untuk menggambarkan pemahaman siswa tentang materi bangun datar berdasarkan teori APOS.

Soal yang digunakan dalam penelitian ini adalah sebagai berikut:

Paman mempunyai taman berbentuk Persegi dengan luas taman 484 meter. Paman ingin menanam pohon apel di taman nya tersebut dengan jarak masing-masing pohon ialah 2 meter. Berapa banyak pohon apel yang dapat ditanam oleh paman?

\section{Hasil dan Pembahasan}

Hasil jawaban dari setiap siswa memiliki hasil jawaban yang sama, maka peneliti akan memilih salah satu jawaban siswa untuk dijadikan sampel penelitian. Berikut hasil analisis tes siswa yang telah dilakukan melalui Google Form adalah sebagai berikut: 


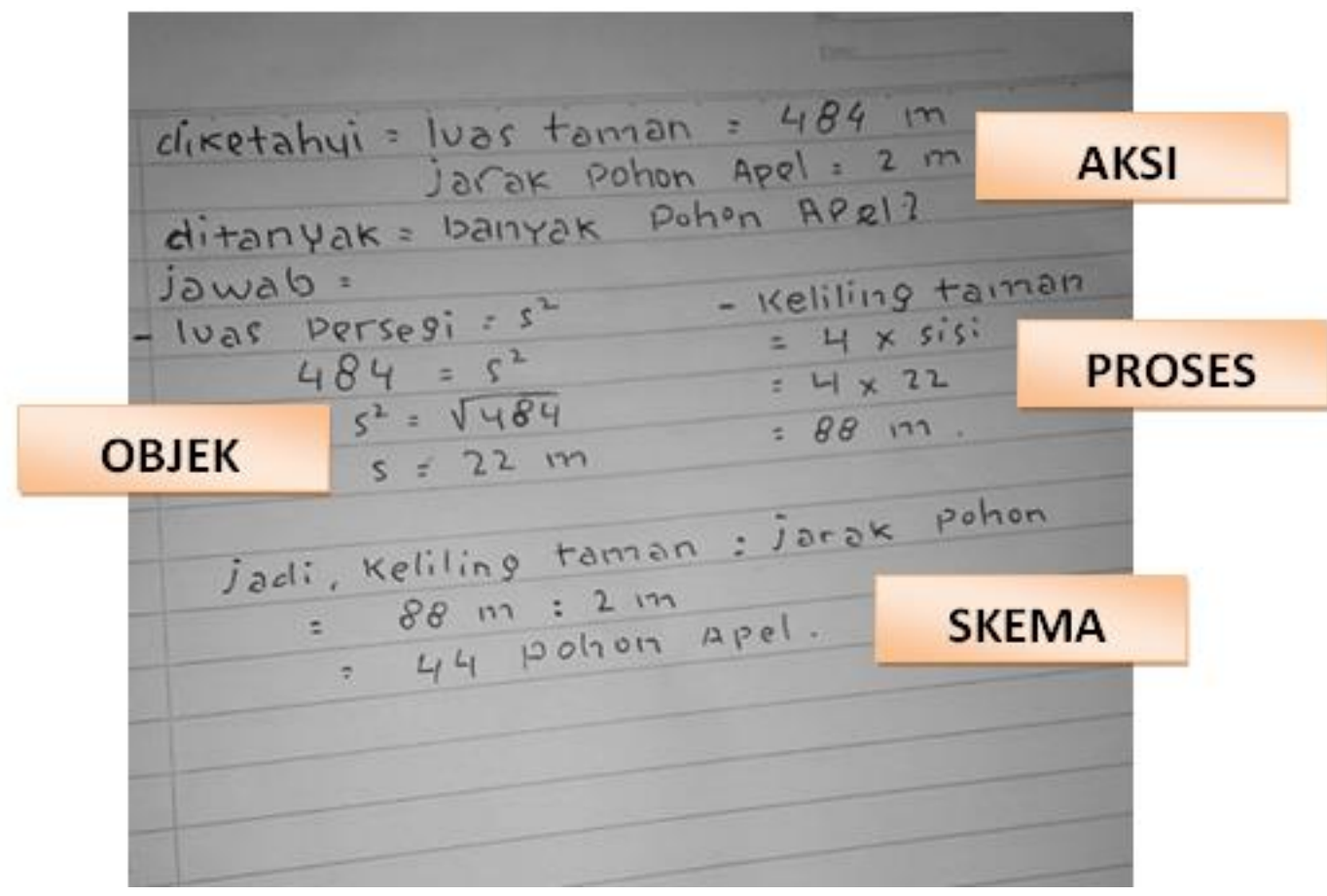

Gambar 1 Hasil jawaban siswa

Berdasarkan gambar 1 di atas dapat dilihat bahwa Siswa telah mencapai indikator mengaplikasikan konsep atau algoritma dalam pemecahan masalah. Hal ini dibuktikan dengan mampu menyelesaikan soal dengan meberikan jawaban tahap aksi, proses, objek dan Skema. Siswa menuliskan apa yang diketahui dan ditanyakan dalam soal, luas taman yaitu 484 meter dan jarak antar pohon apel yaitu 2 meter yang sudah diketahui terlebih dahulu. Selanjutnya pada tahap objek, untuk mendapatkan panjang sisi sebuah persegi tersebut, siswa mengaitkan permasalahan dengan rumus luas persegi yaitu $\mathrm{s} \times \mathrm{s}$ atau $\mathrm{s}^{2}$, dimana luasnya adalah 484 meter. Kemudian didapat panjang sisi nya yaitu 22 meter. Langkah selanjutnya, siswa menggunakan rumus keliling persegi yakni $\mathrm{K}=4 \times 22$ meter. Ditemukan hasil keliling taman yaitu $88 \mathrm{~m}$. kemudian, untuk mencari banyak pohon yang dapat ditanami dalam taman, siswa membagi hasil dari keliling dengan jarak antar pohon yang ada, jadi $88: 2=44$ pohon apel. Jawaban yang diberikan 
oleh siswa pada soal ini, memuat 4 tahap APOS, yakni Aksi, Proses, Objek, dan Skema.

\section{Kesimpulan}

Berdasarkan hasil penelitian diatas dapat disimpulkan bahwa sebagian besar siswa memiliki kemampuan pemahaman pada permasalahan bangun datar berdasarkan 4 tahap teori APOS, yaitu yakni Aksi, Proses, Objek, dan Skema. 


\section{Daftar Pustaka}

[1] Intisari, I. (2017). PERSEPSI SISWA TERHADAP MATA PELAJARAN

MATEMATIKA. Wahana Karya Ilmiah Pendidikan, 1(01).

[2] Kusaeri, K. (2017). Terbentuknya konsepsi matematika pada diri anak dari perspektif teori reifikasi dan APOS. Jurnal Pendidikan Matematika (JPM), 1(2), 101-105.

[3] Rahmawati, M., Uswatun, D. A., \& Maula, L. H. (2020). Analisis pemahaman konsep matematis siswa berdasarkan teori apos melalui soal open ended berbasis daring di kelas tinggi sekolah dasar. Didaktik: Jurnal IImiah PGSD STKIP Subang, 6(1), 155-165.

[4] Susanto, Ahmad. (2014). Teori Belajar dan Pembelajaran Di Sekolah Dasar (edisi 1). Jakarta: Kencana Prenadamedia Group.

[5] Suwanto, F. R., Aprisal, A., Putra, W. D. P., \& Sari, R. H. Y. (2020, September). APOS Theory towards Algebraic Thinking Skill. In Ahmad Dahlan International Conference on Mathematics and Mathematics Education (Vol. 1, No. 1, pp. 52$58)$.

[6] Syafri, F. S. (2016). PEMAHAMAN MATEMATIKA DALAM KAJIAN TEORI APOS (Action, Process, Object, and Schema). Jurnal At-Ta'lim. 15 (2), 458-477. 